\title{
SCRIPTURE AS A SOURCE OF CHEMNITZ' CHRISTOLOGY
}

Martin Chemnitz uses careful exegesis and Biblical scholarship to interpret the relevant texts pertaining to the sacraments in the Scriptures. Though a good systematic theologian, he does not deduce the teaching about the real presence Christ's body and blood under the elements of the bread and wine in the Lord's Supper directly from Christology. He uses the Christological teaching only as a necessary metaphysical framework for a thorough interpretation or relevant biblical texts. The sedes doctrinae (the roots and seeds of the doctrine) can be found in the words of institution in the Gospel of Matthew, Mark and Luke. These are the words of Christ himself, which constitute His last will and testament for the church worldwide to follow.

\section{Introduction of the problem}

According to Chemnitz' thinking "The Scripture forms a protective border against the distortion and false interpretation of the Christian message." If we can consider this conclusion to be true, a logical continuation of examining the sources of Chemnitz' Christology in his teaching about the Lord's Supper will be a thorough analysis of Chemnitz' interpreting approach to relevant biblical texts. The object of this analysis will be especially Chemnitz' key book about the issue of the Lord's Supper - De Coena Domini - and four other works (in chronological sequence): Anatome propositionum Alberti Hardenbergii de Coena Domini (1561 - one of Chemnitz' first works. The book was written against pastor Albert Hardenberg who was drawn to Calvinist thinking); Examen concilii Tridentini (1566-73 - The polemic in this book is written into a completely different context than Anatome or De coena Domini (originally: Fundamenta sanae doctrinae...). It deals with the polemic with Roman Catholicism where new emphases were laid and different questions had to be answered); De duabus naturis (1580 This work contains the most complexly developed Lutheran Christology in the $16^{\text {th }}$ and $17^{\text {th }}$ century. Due to its complexity and richness of quoted sources it is still important even today); Loci Theologici (published after Chemnitz' death by Polycarp Leyser, 1591).

We will pay attention not only to his approach towards the texts and his way of interpretation, but also to the historical context within which these works arose. We will observe to what extent the content and form of Chemnitz' arguments were influenced by polemic situations in which he found himself as well as by Chemnitz' enduring pastoral interest.

\section{Words of Institution as a Normative Source for the Teaching about the Lord's Supper according to De coena Domini (1570)}

We find the most complex view about the Lord's Supper and about the Christological issues connected with it in Chemnitz' work De coena Domini. [1] Chemnitz wrote it within the context of the polemic with Cryptocalvinists and Zwinglists. This fact is visible in his way of argumentation. His explanations try to answer both spoken and unspoken questions and objections of his opponents such as Karlstadt, Oekolompadius, Bucer, and especially Hardenberg and his followers. His exegesis is not as fresh and unbiased as at times when it was not necessary to fight with his opponents.

This book is based on four former partial works dealing with this problem which Chemnitz wrote in the beginning of his theological career in connection with his polemic with Albert Hardenberg. These works include the following: Anatome Propositionum Alberti Hardenbergii De Coena Domini; Die Reine Gesunde Lehre Von Der Wahren Gegenwertigkeit Des Leibs Und Bluts Christi in Seinem Abendmal; Leuterung Der Proposition Oder Schlusreden Alberti Hardenbergers Von Dem Abendmal Des Herrn; and Repetitio Sanae Doctrinae De Vera Praesentia Corporis Et Sanguinis Domini in Coena.

\section{The Goal of the Book}

In his book Fundamenta Sanae Doctrinae, which became famous under the title De Coena Domini, Chemnitz presents a mature and thorough theology of the Lord's Supper. He uses his common theological method here as well. First he deals with Scripture and exegesis. Already in his "Letter of Dedication" in the beginning of the book he introduces his main goal which he follows throughout his work - " to remain faithful to the words of the covenant of the Son of God and to respect them piously and sincerely in order not to want to know more or to be able to listen to something else in this argument than to the holy words of the Son of God, our Savior, which he commanded us in the form of his last will or testament in the night when he was betrayed." [6] He is not trying to see something new. He does not want theological prestige. He is trying to be faithful to the Scripture and the reformed way of inter-

\footnotetext{
* Michal Valčo

Department of Pedagogy, Psychology and Social Sciences, Faculty of Science, University of Zilina, Slovakia, E-mail: michal.valco@fpv.utc.sk
} 
pretation of Christ's words of institution. He continues saying, "I did not desire to bring anything new. I simply tried to keep the original, basic, and simple teaching and to repeat it on the basis of Luther's writings, i.e. that the dogma (teaching) about the Lord's Supper has its own important and specific context (sedes doctrinae) in the words of institution and we should seek its true meaning in these words." We need to observe that Chemnitz does not keep only to the importance of keeping the right exegetic method, i.e. start with the exegesis of the Scripture and if possible keep with the literal meaning of the words unless the context clearly shows a completely opposite meaning. We find that he greatly honors Christ's words of institution "because they are the words of the last will and testament of the Son of God Himself" and because "one cannot approach them lightheartedly and arbitrarily and one has to consider them with respect and pious devotion." [6]

For Chemnitz the most compelling arguments within the framework of the theological debate about the Lord's Supper were those that sprung from "a comparison, congruence, and mutual explanation of those four texts of the Scripture that directly deal with the institution of the Lord's Supper: Matthew 26, Mark 14, Luke 22, and First Corinthians 11". [1, 2, 3, 4, 5, 6] He thinks it remarkable that "the Holy Ghost wanted to show, teach, and confirm through these repetitions the true, certain, and pure interpretation and meaning (of these words)." [4,5,6] Chemnitz supposed that Matthew was the first to write his gospel, then Mark, then Luke, and finally apostle Paul repeated Christ's words of institution in his letter. All of these texts are analyzed in detail. The used expressions are compared with the rest of the texts of the words of institution. In none of these passages does he find even a hint of allegorical or other then literal interpretation.

Therefore it is not surprising to the reader that Chemnitz challenges all Christians in the very first chapter that they do not approach the words of the Lord's Supper lightheartedly, but with great awe before the Lord and in obedience of faith. This emphasis becomes the main motto not only of the first chapter, but also of the whole book. It concerns the last testament of God's Son. Therefore Chemnitz rejects three false exegetic approaches to the given passages.

\section{Exegetic Approaches to the Words of Institution of the Lord's Supper}

According to the first approach the words of institution should simply be ignored at least for the present (this was Schwenckfeld's opinion). The second approach was liberal in a sense that it made such an interpretation or a change of the words of institution possible that anyone could adapt them at their will. According to the third approach it did not matter at all how one interpreted the given words because they did not endanger faith and salvation. As a result the interpretation of the words of institution should be immune against any criticism.

Chemnitz rejects such approaches radically. The words of God's Son that He said at the Last Supper to His disciples cannot be ignored or taken lightheartedly or misunderstood without "having an influence on the faith and salvation of man." [6] Here he quotes Dt 5:32, 4:2 and John 15:7 which admonish people to be careful how they approach the testimony of the Scripture. Apostle Paul states something similar in his First letter to Corinthians, and Chemnitz readily points this out. He notices Paul's threat of judgment over the one who would approach the mystery of Christ's body lightheartedly: "For anyone who eats and drinks without recognizing the body of the Lord eats and drinks judgment on himself." (1 Cor 11:29) There is a lot at stake. The Lord's Supper is closely connected to a person's faith and thus also to his/her salvation or condemnation. Chemnitz realizes clearly that the sinner has to understand this issue in the right way. Christ offers him/her the assurance of His merciful presence. Since Christ's presence is at stake, everything is at stake.

If we want to have a solid and sure foundation, we need to place our understanding of the Lord's Supper on a right understanding of His (the Lord's) words of institution. Chemnitz criticizes the theological method of sacramentarians because they base their understanding of the essence and meaning of the Lord's Supper not on Christ's words of institution, but on other passages most of which are not connected to the topic of the altar sacrament at all: "... they come with prejudices which they created on the basis of other passages of Scripture most of which do not talk about the Lord's Supper." [6] Chemnitz considers such an exegetic and hermeneutical approach as illegitimate and dangerous.

It is a fact that the Scripture tells of many doctrines in different places, such as the institution of marriage (Gen 1 and 2). Chemnitz agrees with the rule that in such cases the original text has a superior position and other passages talking about the same topic need to be interpreted in its light (e.g. the possibility of divorce in Dt 24:1-4). However, the Lord's Supper is a very specific case. Christ has given this gift to His disciples and thus to His whole church only on the final night when He was betrayed. We have three gospel passages in the Scripture which tell of the institution of the Lord's Supper and each of them has the same context - it is the last night of the Lord with His disciples. It is His last will! In his first letter to the Corinthians Paul quotes the words of institution of the Lord Himself („For I received from the Lord what I also passed on to you ...”; 1Cor 11:23) and these words are again the very same as the words we find in the gospels. [7] (In his article about the dangers of rash ecumenism Ernst Volk emphasizes the authority of Christ's words of institution and expresses his opinion saying that Chemnitz uses the so-called Pauline tradition (in close connection with Luke) "not only as a pure historical formulation, but also as a certain rule and norm according to which the Lord's Supper should be carried out." He talks about it in connection with the "questionable exegetic situation" of the present times when many exegetes try to doubt its historicity through historical and critical analysis and thus the validity and relevance of a text for the present church). Neither the church nor the disciples had these words before that last night.

"God's Son in the night when He was betrayed, instituted this dogma (this teaching) and did so with definite words, ... so that 
this teaching would be handed on and would be distinguished in the church according to this rule to the end of times." [6] According to Chemnitz this is the reason why we cannot look for other passages in the Scripture in the light of which we would interpret Christ's words of institution of the Lord's Supper. This would be exegetic inconsistency. Such a theological method would be extraordinarily unreliable and would enable arbitrary allegorical interpretation of any biblical passage. There is no other passage that would talk about the institution of the Lord's Supper other than the words of institution in the gospels and in 1 Corinthians.

According to Chemnitz, Theodor Beza has committed such an exegetic inconsistency as well. Even though he was open to say that "the Lord's Supper does not consist only of the symbols of bread and wine, but also of the substance of the body and blood of Christ; ... and that the Lord's Supper does not communicate only symbols (to people), but also, the true body and blood of Christ." $[1,5,6]$ However his metaphysical suppositions or better said prejudices predestine him to a wrong Christology which influences his exegetic approach to Scripture! Due to his different metaphysical prejudices and the Christology based on them, Beza cannot agree with the way how Christ is present in the bread and wine in the Lord's Supper. That is why Beza prefers other texts from the Scripture which spiritualize Christ's presence. These are especially the following verses from the gospel of John:

"Jesus answered, "I tell you the truth, you are looking for me, not because you saw miraculous signs but because you ate the loaves and had your fill. Do not work for food that spoils, but for food that endures to eternal life, which the Son of Man will give you... The Spirit gives life; the flesh counts for nothing. The words I have spoken to you are spirit and they are life." (The most favorite passage is from the gospel of John 6:2629.35.51-56.63;

On the basis of this text Beza said that the substantial, bodily presence of Christ is not necessary for believers because the above quoted text from the gospel according to John says, "The Spirit gives life; the flesh counts for nothing." Beza used these words to interpret Christ's "testament", as Chemnitz calls it, i.e. the words of the institution of the Lord's Supper.

Chemnitz reproaches Beza and other theologians who think alike for their exegetic inconsistency and wrong hermeneutical approach because the above mentioned passage from John 6 is not placed within the context of the Last Supper. The words of institution are not mentioned there and thus it does not talk about the institution of the Lord's Supper. That is why Chemnitz directs his attention to the words of the texts which talk directly about the institution of the sacrament of the Lord's Supper. There Christ talks about the taking of the sacrament through the mouth of the believers (manducatio oralis). "Take it; this is my body." (Mk 14:22) „We are not allowed," says Chemnitz, "to argue about the appropriate and more important kind of presence and of taking, but we should believe with awe, and support such presence about which God's Son tells us in the words of His last will and testament, even if it seemed absurd to our human reason." The human ratio has to yield to God's revelation. The trustworthiness of the words of Scripture is not determined by their content and human logic, but by their source. Since the words of institution originate from the Lord of the church Himself, we do not have reason to think that $\mathrm{He}$ deceives or misleads us by them. His words "will never pass away", and thus we should adhere to them, unless it is absolutely clear that the natural, literal meaning should be forsaken - and that can happen only on the basis of other passages in the Scripture which have the same context and talk about the same thing - the natural, simple, and literal meaning of the given text should be preserved. Otherwise we are apt to fall into the danger of arbitrary interpretation, one-sided spiritualization, and individualism.

Apart from this methodological criticism, Chemnitz also presents a criticism of the metaphysical suppositions of Beza's (and of the whole reformed-calvinist) theology. Beza's statement according to which Christ's presence and the mediation of his benedictions are more real, more efficient, and more important when they happen in the heart through faith than when the sanctified elements are taken through the mouth (the so-called manducatio oralis),[6] in Chemnitz' opinion reveals the underestimation of matter as God's good creation. This is the old platonic dualism of spirit and matter, intellectual and sensual perception of reality.

\section{The Relationship of the Right Interpretation of the Words of Institution to Christology}

This question is closely connected with other parts of the Scripture which create the basis for Christological concepts and the teaching of the church. Who is Jesus Christ according to the Scripture? What does the unity of the divine and human nature in the person of God's Son - Jesus of Nazareth - mean? How does this "unio personalis" influence Christ's human nature - in other words: are the physical characteristics of the human body of Jesus Christ a limiting factor in his acting and presence in the elements of the Eucharist? How can we explain the biblical passages which talk about Christ's ascension and His being seated at the right hand of God?

One cannot avoid these questions when we ask with Chemnitz, "What is present in the Lord's Supper, what is given and what do the participants take in with their mouths?" It cannot be avoided because a very important thing is at stake. It cannot be avoided because the basic question of Christology: "Who is Jesus Christ?" is inseparably connected to the question concerning His presence in His holy supper.

According to Chemnitz, we can find the answer in the introductory words of the institution: "This is my body, which is for you; do this in remembrance of me. ... In the same way, after supper he took the cup, saying, This cup is the new covenant in my blood ..." (1 Cor 11:23).[5] These words talk about the essence of the sacrament (essence, substantia). In Chemnitz' opinion only on the basis of a right understanding of these words can we understand the benefit (beneficum), the blessings of this sacrament. "Do this in remembrance of me.” This part of Christ's words of institution 
speaks about the benefit of the sacrament, about its meaning and mission. Chemnitz comments here that "in remembrance of me" means "that you may remember that my (Christ's) body which you take was given for you and that the blood which you drink was shed for the forgiveness of sins. And there are also the words: 'This cup is the new covenant in my blood.' These words do not talk about some historical, cold or inactive memory, but about a true faith which takes hold of Christ and which will take Christ with all His merits and benefits for reconciliation, salvation, and eternal life.”[6]

So the first part of the words of institution in the Scripture talks about the sacred taking of the true body and blood of the Lord Jesus Christ through the real taking of the sanctified bread and wine through the mouth of a person (i.e. manducatio oralis). The second part talks about the spiritual eating (i.e. manducatio spiritualis) or the spiritual taking of Christ and His blessings if the person participating in the act of oral taking (manducation oralis) on the basis of Christ's invitation believes that he/she partook in the true body and blood of the Lord and thus also in all the blessings which flow out of God's promises. These two aspects have to be carefully distinguished within the framework of the sacrament. Both of them are important and they take place at the same time. Neither one can be neglected to benefit the other because as Paul says there would arise the danger of eating and drinking judgment on oneself. Chemnitz' emphasis is expressed in the principle that one cannot have Christ and His blessings (reconciliation, righteous- ness, forgiveness, new life, salvation,...) $[1,3,4]$ in the sacrament of the Lord's Supper without His real and true body. Chemnitz, like Luther, knows no other Christ than the one who was crucified in the body and who rose from the dead in the body.

\section{Conclusion}

In his main work about the Lord's Supper, Chemnitz does not deduce the teaching about the real, bodily presence of the whole glorified Christ under the sanctified elements of the bread and wine in the Lord's Supper directly from Christology. He uses the Christological teaching with its typical concepts "unio personalis (hypostatica)", "perichoresis" and "communication idiomatum" only as the necessary metaphysical framework for a thorough interpretation or relevant biblical texts. $[1,2,3,4]$ This is an interesting theological approach that is lost gradually with the later generations of reformers. Honest exegesis and legitimate hermeneutics are replaced by theological deduction of the later Lutheran orthodoxy. The theological method based primarily on theological deduction is open and jeopardized by theological and metaphysical speculation which Chemnitz tried to evade. Regardless of the fact to which degree he really succeeded, we can state that his emphasis on authentic interpretation of carefully selected Scripture texts - the so-called sedes doctrinae - is very remarkable for its time and it is worth following even in our age.

\section{References}

[1] CHEMnITZ, M.: Fundamenta Sanae Doctrinae De Vera Et Substantiali Praesentia, Exhibitione Et Sumptione Corporis Et Sanguinis Domini in Coena, Repetita a Martina Chemnitio, Jenae, 1570

[2] CHEMNITZ, M.: Anatome Propositionum Alberti Hardenbergii De Coena Domini... Et: Declaratio Articule Decimi in Confessione Augustana De Coena Domini... (Ins Deutsche Gebracht Durch Johannes Zanger), Eisleben, 1561

[3] CHEMnITZ, M.: Die Reine Gesunde Lehre Von Der Wahren Gegenwertigkeit Des Leibs Und Bluts Christi in Seinem Abendmal, Wie Dieselbe in Den Evangelischen Kirchen Der Augspurgischen Confession Verwandt Bissanher Gelehret Ist Und Noch Gelehret Wirdt, in Kurtze, Deutliche, Einfeltige Heuptstücke Im Latein Zusamengezogen Durch M.Martinum Kemnitz ... Jetzundt Aber Dem Einfeltigen Leser Zugut Ins Deutsch Verfertiget Durch Johannem Zanger, Lipsiae, 1561

[4] CHEMNITZ, M.: Leuterung Der Proposition Oder Schlusreden Alberti Hardenbergers Von Dem Abendmal Des Herrn, Welche Er Auff Dem Kreistag Zu Braunschweig Den Stenden Des Nidersechsischen Kreis Ubergeben Hat. Sampt Erklerung Des Zehenden Artickels Der Augspurgischen Confession, Wie Die Lere Vom Abendmal Des Herrn Bey Lutheri Zeit Und Leben Verstanden Sey Worden. Auch Von Den Propositionibus Oder Schlussreden Der Prediger Von Bremen Etc. Zuvor in Latein Gestellet Durch Herrn M. Martinum Kemnitz, Itzt Aber Ins Deutsche Gebracht Durch Johannem Zanger, Eisleben, 1561

[5] CHEMNITZ, M.: Repetitio Sanae Doctrinae De Vera Praesentia Corporis Et Sanguinis Domini in Coena, Additus Est: Tractatus Complectens Doctrinam De Communicatione Idiomatum, Lipsiae, 1561

[6] CHEMniTZ, M.: The Lord's Supper = De Coena Domini, trans. J. A. O. Preus, St. Louis, Concordia Pub. House, 1979

[7] VOLK, E.: Evangelical Accents in the Understanding of the Lord's Supper, Lutheran Quarterly I, 2/1987, p.180-195. 